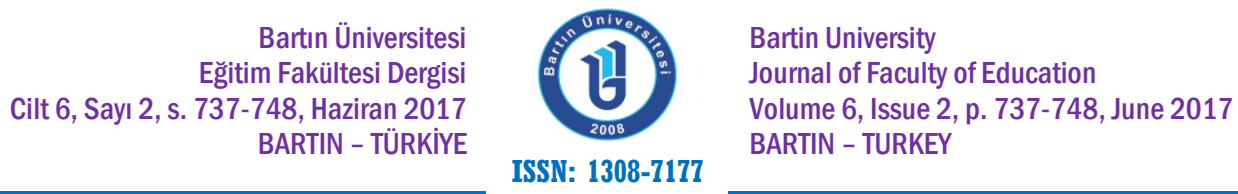

Doi: 10.14686/buefad.308908

\title{
Sınıf ve Okul Öncesi Öğretmenlerinin Değer Öğretimine İlişkin Görüşleri
}

Muamber YILMAZ, Doç. Dr, Bartın Üniversitesi Eğitim Fakültesi, muammeryilmaz66@gmail.com

Ömer Faruk YILMAZ, Öğretmen, Kabagöz İlkokulu, omerfaruk663@mynet.com

Öz: Bu araştırmada sınıf öğretmenleri ile okul öncesi öğretmenlerinin değer öğretimi hakkındaki görüşlerini belirlemeye çalışmaktır. Araştırmanın evrenini Bartın il merkezinde görev yapan 260 sınıf ve okul öncesi öğretmeni oluşturmaktadır. Örneklemi ise yansız küme örnekleme yöntemiyle seçilen 80 sınıf ve okul öncesi öğretmeni oluşturmaktadır. Araştırmada tarama modeli kullanılmıştır. Veri toplama aracı olarak Akbaş (2004) tarafından geliştirilen “Değer Öğretiminde Kullanılan Etkinlikler ve Değer Öğretimine İlişkin Görüşler Ölçeği" ölçme aracı olarak kullanılmıştır. Elde edilen verilerin analizinde frekans, yüzde, aritmetik ortalama, bağımsız gruplar t-testi ve tek yönlü varyans analizi kullanılmıştır. Araştırma sonucunda, öğretmenlerin değer öğretimine yönelik görüşlerinin cinsiyete ve mesleki kıdeme göre anlamlı bir farklılık göstermediği belirlenmiştir. Sınıf öğretmenleri ile okul öncesi öğretmenlerinin değer öğretimine ilişkin görüşleri arasında anlamlı bir farklılık olduğu, bu farklılığın sınıf öğretmenleri lehine olduğu belirlenmiştir. Okul öncesi ve sınıf öğretmenlerinin değer öğretimine yönelik genel algı puanlarının $x=3,82$ olduğu belirlenmiştir. görüşleri

Anahtar Kelimeler: değer, değerler eğitimi, sınıf öğretmeni, okul öncesi öğretmeni, öğretmen

\section{Opinions of Primary School and Pre-School Teachers about Value Education}

\begin{abstract}
In this research, the opinions of primary school teachers and pre-school teachers on value education were evaluated. The population of the study constitutes 260 primary school teachers and pre-school teachers in the Bartın city center. The sample consists 80 primary school teachers and pre-school teachers, which are chosen by randomly sampling method. Survey model was used in the research. It was used data collection tool "Activities used in value education and scale of opinions on value education" developed by Akbaş (2004). In the analysis of datas used frequency, percentage, mean, independent groups t-test and one way anova. As a result of research was found nonsignificant difference according to gender and professional experience views on the value education of teachers. It was found significant primary school teachers' favor, between primary school teachers and pre-school teachers. It was determined general perception score $(x=3.82)$ opinions of primary school teachers and pre-school teachers on value education.
\end{abstract}

Key Words: value, values education, primary school teachers, pre-school teachers, opinions of teachers 


\section{GíRiş}

Değer eğitiminin önemi son yıllarda daha da artmıştır. Eğitimin hedeflerinden biri toplum tarafından kabul edilen değerleri davranış haline getiren bireyler yetiştirmektir. Değerler dolaylı ya da dolaysız olarak bireylerin davranışlarını yönlendirmektedir. Bireylerin hangi davranışların toplum tarafından kabul edilebilir olduğunu öğrenmesi için yardıma ihtiyaçları vardır. Bu yardım değerler eğitimiyle sağlanmaktadır.

Bu kavramın güncelleşmesi ile değerlere ne kadar ihtiyaç duyulduğu anlaşılmaktadır (Tahiroğlu, Yıldırım ve Çetin, 2010). Değerler, toplum ya da bireyler tarafından kabul edilen, sosyal ihtiyaçları karşıladığı düşünülen, bireylerin davranışlarına yön veren, toplum bütünlüğünü sağlayan, doğru ile yanlışı ayrıt eden ve huzurlu bir yaşam sürmemize yardım eden yargılardır (Balcı ve Yanpar Yelken, 2010; Fidan, 2009; MEB, 2005; Öztürk, 2009; Turan ve Aktan, 2008). Değer; toplumlar veya insanlar tarafından kabul edilmiş ve yaşatılmakta olan her türlü ideolojik veya ilahi kaynaklı duyuşsal, bilişsel, davranışsal, kural ya da kıymetlerdir (Dönmez ve Yazıcı, 2008). Başka bir ifade ile değer, bir durumu başka bir duruma tercih etme eğilimidir (Genç ve Eryaman, 2007).

Değerin özellikleri şöyle sıralanabilir:

1. Değerler toplum ya da bireyler tarafından kabul gören yargılardır.

2. Sosyal ihtiyaçları karşıladığı düşünülen ölçütlerdir.

3. Sadece bilişsel değil aynı zamanda duyuşsal yargılardır.

4. Değerler bireyin davranışını yönlendirmektedir.

5. Değerler normlara göre daha genel ve soyut bir nitelik taşımaktadır. Çünkü değerler normları da içermektedir (MEB, 2005).

Yazıcı'ya (2006) göre bu özelliklere sahip değerler sisteminin fonksiyonları şöyle sıralanabilir:

1. Bireye hedef tayin eder.

2. Bireysel ve toplumsal faaliyetlerin esaslarına yön verir.

3. Bireylerin davranışlarını değerlendirmesine yardım eder.

4. Bireyin başkalarından ve kendisinden ne beklendiğini bilmesini sağlar.

5. Doğruyu ve yanlışı, haklıyı ve haksızı, hoşa gideni ve gitmeyeni, ahlâkî olanı ve olmayanı ayırt etmeyi sağlar.

Değerler doğuştan getirilmeyip, sonradan kazanılmaktadır. Bu nedenle, bireyin belirli değerleri farketmesi, kabullenmesi, yeni değerler üretmesi ve kendine mal etmesi eğitimle ilgilidir. Değerlerin kazanımı bir eğitim işidir. Eğitimin amacı bireylere, toplumun değer sistemini kazandırmaktır. Bu nedenle okul, bireylere değer kazandırmada kullanılan etkili araçlardandır (Yeşil ve Aydın, 2007).

Değer eğitimi, bireyin insana özgü olanaklar, insanı insan yapan nitelikler, insanı diğer canlılardan farklı kılan özellikler açısından gelişmesine yardımcı olmaktır.

Değerler eğitiminin bazı özellikleri şunlardır:

1. Bireyleri kültürel ve evrensel değerler konusunda bilinçlendirmek,

2. Demokratik tutumlar ve hoşgörüyle çok kültürlülüğü ilişkilendirmek,

3.Tüm değerleri insanın var olma şartlarını geliştirme ölçütüyle değerlendirmek,

4. Etik değerlerle ilgili somut problemlerden hareketle bilgiyi hayata dönüştürmek (Kale, 2007).

Değer eğitiminin, karakter eğitimi ve ahlaki gelişimi kapsadığı söylenebilir (Demircioğlu ve Tokdemir, 2008). Değer eğitiminde temel amaç hem toplumsal hem de evrensel değerlere sahip ve sahip olduğu değerleri davranışlarıyla gösteren bireyler yetiştirmektir. 
Milli Eğitim Bakanlığı (2006), değer eğitimine yönelik bazı öğretim yaklaşımları önermektedir. Bunlar: Değerleri betimleme, ahlaki muhakeme, değerleri analiz etme ve gözlem yoluyla öğretim yaklaşımıdır. Değerleri betimlemek, öğrencilerin sahip oldukları değerler hakkında bilgilendirilmesini kapsamaktadır. Ahlaki muhakeme, öğrencilere farklı ahlaki ikilemler sunarak onları karşılaştırma yapmaya teşvik etmeyi içermektedir. Değer analizi, değerlerin nedenleri üzerinde öğrencileri düşündürmeyi amaçlamaktadır. Gözlem yoluyla değer öğretimi ise öğrencilere, değerlerin gözlemle kavratılmasını ifade etmektedir. Öğretim programlarında öğrencilerelere değer kazandırma işlevi çoğunlukla hayat bilgisi, sosyal bilgiler, vatandaşlık ve insan hakları eğitimi dersleriyle yapılmaktadır (Oğuz, 2012).

Önceki eğitim programlarında yer alan değer öğretimi ile ilgili ifadeler yetersiz olamasına rağmen öğretmenler tarafından örtük program dâhilinde sunulduğu ifade edilmektedir. Doğanay (2006), örtük program dâhilinde nitelendirilen değer eğitiminin, planlı öğrenme yaşantılarıyla gerçekleştirilmesi gerektiğine vurgu yapmaktadır. Şen (2007) ise artık değer eğitiminin örgün eğitim kurumlarında formal bir program içinde yapıldığını belirtmektedir.

Dünyada ve ülkemizde, eğitim yaşantısına dahil edilen birbirinden farklı değerler eğitimi programları mevcuttur. Ülkemizde iki temel değerler eğitimi programı dikkat çekmektedir. Bunlardan biri karakter eğitimi diğeri ise yaşayan değerlerdir. Karakter eğitimi; program aracılığıyla bireylere, temel insani değerleri kazandırma, değerlere karşı farkındalık oluşturma ve değerleri davranışa dönüştürme konusunda bireylere yardımcı olmayı içermektedir. Karakter eğitiminin amacı; çocukluk çağında ahlaki değerleri olan, gençlik çağında ise performansını en iyisini yapmaya sarfeden, doğru işler yapan ve yaşantısının amacını bilen bireyler yetiştirmektir. Yaşayan değerler eğitim programı ülkemizde MEB tarafından da onaylanmakta ve desteklenmektedir. Değerler eğitimi, Yaşayan Değerler Eğitim Programı (YDEP) adı altında 1995 yıında Birleşmiş Milletlerin 50. yıl dönümü kutlamaları için Brahma Kumaris tarafından hazırlanan bir proje olarak uygulanmıştır.

UNESCO tarafından desteklenen bu eğitim, eğitimciler tarafından "Yaşayan Değerler Eğitimi" adıyla kabul edilmiştir. Yaşayan Değerler Eğitimi programında işbirliği, dürüstlük, sevgi, özgürlük, barış mutluluk, alçakgönüllülük, hoşgörü, saygı, sorumluluk, sadelik, birlik olarak 12 evrensel değer esas alınmıştır (Bacanlı ve Dombaycı, 2012).

Değerler bireye sonradan kazandırılmaktadır. Bundan dolayı aile, okul ve toplumun bireye değer kazandırmada önemli sorumlulukları bulunmaktadır. Okula başlayıncaya kadar çocuklara hangi değerlerin kazandırılacağı hususunda en temel kurum ailedir (Aydın ve Akyol Gürler, 2013). Ancak teknolojik gelişmeler ve küreselleşme sonucunda toplum yapısında bir takım değişiklikler meydana gelmiştir- (Dilmaç, 2002). Bu değişiklikler ailede başlayan değer eğitim sürecini de etkilemiştir. Evde annenin çalışyor olması, parçalanmış aile yapısı, çalışan anne-babaların eve geç gelmesi çocukla geçirilen süreyi kısaltmaktadır. Bu durum çocuğa değer aktarımını sekteye uğratmaktadır. Çocukla geçirilen sürenin azalması, çocuğun daha fazla televizyon seyretmesine neden olmaktadır. Çocuklar televizyonda sunulan programlarda bazen doğru veya yanlışı ayırtedememektedirler. Değer eğitimi sürecinde ortaya çıkan bu boşluk çocuklara değer öğretimini zorlaştırmaktadır. Hatta onların yanlış değerler kazanmalarına sebep olmaktadır (Alpöge, 2011). Bu noktada çocuklara değer kazandırmada öğretmen rölü önemi bir yere sahiptir.

Konuyla ilgili alan yazın tarandığında şu araştırmalara rastlanmaktadır:

Deveci (2015) araştırmasında, değerler eğitiminin toplum için önemli olduğunu, toplumsal düzenin sağlanması için ailede ve okulda değerlerin kazanılması gerektiğini, her bireyin dürüstlük, saygı ve hoşgörü gibi temel değerlere sahip olması gerektiğini ifade etmiştir. 
Çetingöz (2012) okul öncesi eğitimi anabilim dalı öğretmen adaylarının değerler eğitiminde öğretmenin rolünü belirlemek amacıyla yaptığı çalışmada, öğretmen adaylarının görüşlerinin; değer olarak öğretilebilebilecek kavramlar, değer eğitimi uygulamaları, değer eğitimi uygulamalarında kullanılabilecek materyaller ve değer eğitiminde okul-aile işbirliği temaları altında toplandığını ifade etmiştir. Şahinkayası ve Kelleci (2013) yaptıkları araştırmada, öğretmenlerin değerler eğitiminde kullandıkları eğitim materyallerinin ve etkinliklerinin yetersiz olduğunu, değer eğitimi uygulamalarının günlük yaşamdan örnekler vermekle ve hikâyeler okumayla sınırlanırıldığını belirtmişlerdir. Bunun yanında değerler eğitiminde öğretmenlerin teknolojiden yeterince yararlanmadıklarını ifade etmişlerdir. Fidan (2009) öğretmen adayları üzerinde yaptığı araştırmada; değerler eğitiminde öğrencilere model olunması, değerleri teşvik eden güzel sözlerin öğrencilere okunması, değerlerin farkındalı̆̆ını sağlamak için öğrencilere sorular sorulması, değerleri açıklamaları için öğrencilereler fırsatlar verilmesi, örnek olaylarla değerlerin analiz ettirilmesi gibi etkinlikler yapılması gerektiğini belirtmiştir. Aydın ve Sulak (2012) yaptıkları çalışmada sınıf öğretmeni adaylarının 79 farklı metafor geliştirdiklerini ortaya koymuşlardır. Bu metaforların; zorunluluk olarak değer (27), birleştirici ve şekillendirici olarak değer (21), değişken olarak değer (17), mutluluk kaynağı olarak değer (10) ve yol gösterici olarak değer (4) şeklinde sıralandığını ifade etmişlerdir. Oğuz (2012) yaptığı araştırmada, öğretmen adaylarının en çok evrenselcilik, yardımseverlik ve güvenlik değer tiplerine katıldıklarını tespit etmiştir. Tokdemir (2007) tarih öğretmenleri üzerinde yaptığı araştırmada öğretmenlerin genel olarak değerler ve değer eğitimi ile ilgili yeterli teorik bilgiye sahip olmadıklarını, bunun yanında değerlerin öğretilmesiyle ilgili olumlu tutum içinde olduklarını belirlemiştir. Yıldırım (2009) yaptığı çalışmada değer eğitiminin önce ailede başlaması sonra okulda devam etmesi gerektiğini ifade etmiştir. Yalar (2010) yaptığı çalışmada, şiddet ve saldırganlık içeren yayınların okulda verilen değerler eğitimini olumsuz etkilediğini belirtmiştir. Yazar ve Erkuş (2013) okul öncesi öğretmenleri üzerinde yaptıkları araştırmada kazanılması gereken ilk üç değerin saygı, sevgi ve hoşgörü olduğunu ifade etmişlerdir. Ogelman ve Sarıkaya (2015) tarafından yapılan benzer bir çalışmada kazanılması gereken ilk üç değerin saygı, sorumluluk, sevgi ve hoşgörü olduğu ifade edilmektedir. Thornberg (2008) tarafından yapılan araştırmada ise öğretmenlerin değerler eğitimi uygulamalarındaki algılarının incelenmesinin önemi üzerinde durulmuştur. Altunay ve Yalçınkaya (2011) tarafından yapılan araştırmada bayan öğretmen adaylarının erkek öğretmen adaylarına göre değerlere daha fazla önem verdikleri sonucuna ulaşılmıştır. Yazıcı (2013) değer eğitimyle ilgili yaptığı araştırmada öğretmenlerin değer eğitimine bakış açılarının olumlu olduğu sonucuna ulaşmıştır. Elbir ve Bağcı (2013) değerler eğitimiyle ilgili yapılmış 16 yüksek lisans ve 5 doktora tezini incelemişler, araştırma sonucunda hem öğretmenlerin hem de öğretmen adaylarının değerler eğitimiyle ilgili yeterince bilgi sahibi olmadıkları sonucuna ulaşmışlardır.

Yapılan araştırma sonuçları dikkate alındığında; değer eğitiminin önemine, öğretmenlerin değer eğitimine yönelik bakış açılarına ve değerlerin öğretilmesini olumsuz yönde etkileyen faktörlere vurgu yapıldığı görülmektedir.

Değer eğitimi ailede başlar, bireyin kimlik oluşturduğu döneme kadar devam eder. Çocuğa temel değerleri aşılamak, önce anne ve babaların sonra öğretmenlerin sorumluluğudur. Yanlış gelişmiş bir değeri istenilen başka bir değerle değiştirmek, yeni bir değeri kazandırmaktan daha zordur (Bal, 2004). Bireylerin eğitim hayatı düşünüldüğünde belki de en önemli dönemlerinden biri ilkokuldur. İlkokullarda edinilen bilgi, beceri ve değerler öğrencilerin tüm hayatlarını etkilemektedir. Bunun yanında ilkokulda kazanılan bilgi, beceri ve değerler diğer eğitim kademeleri için bir temel oluşturmaktadır. Bu yüzden ilkokulda değerlerin kazandırılmasına gereken önem verilmelidir. 
Değer eğitimi sürecinde öğretmenler bireyin hayatını anlamlı kılmaya, psikolojik dengeyi korumaya, kişiliği geliştirmeye, ahlak ve karakteri güçlendirmeye çalışmalıdırlar (Aydın ve Akyol Gürler, 2013). Öğretmenlerin, öğrencilere değer kazandırma sürecindeki rolü büyüktür. Değerler eğitiminde öğretmenin rolü, öğrencileri etkileme gücüdür. Öğretmenler konu alanı, seçilen örnekler ve öğrencilere gösterdikleri tepkiler aracılığıyla, belirlenen değerleri öğrencilerde geliştirmeye çalışmaktadırlar (İşcan, 2014). Öğretmenler değerlerin öğrencilere nasıl kazandırılacağı konusunda yeterli bilgiye sahip değillerse, değer eğitiminde örnek teşkil etmiyorlarsa, öğrencilerin kazanmış oldukları değerlerin bile yok olmasına neden olabilirler (Yazıcı, 2006). Değer öğretiminin kazandırılmasının öneminden dolayı araştırmada değer öğretimine ilişkin öğretmen görüşleri incelenmiştir.

\subsection{Araştırmanın Amacı}

Araştırmanın amacı, okul öncesi ve sınıf öğretmenlerinin değer öğretimi hakkındaki görüşlerini tespit etmektir. Bu amaca ulaşmak için aşağıdaki sorulara cevap aranmıştır:

1. Öğretmenlerin değer öğretimi hakkındaki görüşleri cinsiyete göre anlamlı bir farklılık göstermekte midir?

2. Öğretmenlerin değer öğretimi hakkındaki görüşleri mesleki kıdemlerine göre anlamlı bir farklılık göstermekte midir?

3. Öğretmenlerin değer öğretimi hakkındaki görüşleri branş değişkeni açısından anlamlı bir farklılık göstermekte midir?

4. Öğretmen adaylarının değer öğretimi hakkındaki görüşleri genel düzeyde nasıldır?

\section{YÖNTEM}

Araştırmada nicel araştırma yöntemlerinden tarama modeli kullanılmıştır. Tarama modelleri, geçmişte ya da hâlen var olan bir durumu, var olduğu şekilde betimlemeyi amaçlayan araştırma yaklaşımlarıdır (Karasar, 2009). Bu modellerde esas amaç, var olan durumu olduğu gibi betimlemektir.

\subsection{Evren ve Örneklem}

Araştırmanın evrenini 2016- 2017 eğitim öğretim yılında Bartın il merkezinde bulunan ve Milli Eğitim Bakanlığına bağlı resmi okullarda görev yapan 260 okul öncesi ve sınıf öğretmeni oluşturmaktadır. Örneklemi ise evren içinden yansız küme örnekleme yöntemiyle seçilen 80 öğretmen oluşturmaktadır.

\subsection{Veri Toplama Araçları}

Araştırmada veri toplama aracı olarak Akbaş (2004) tarafından geliştirilen "Değer Öğretiminde Kullanılan Etkinlikler ve Değer Öğretimine İlişkin Görüşler Ölçeği" kullanılmıştır. Ölçek Afyon Kocatepe Üniversitesi Eğitim Fakültesi sınıf öğretmenliği ve sosyal bilgiler öğretmenliği bölümü öğrencilerine de uygulanmıştır. Bu ölçek 34 maddelik $5^{\prime}$ li likert tipinde olup, "Kesinlikle Katılmıyorum", "Katılmıyorum", "Kararsızım" , "Katılıyorum", "Kesinlikle Katılıyorum" şeklinde seçeneklerden oluşmaktadır. En düşük ifade için 1 en yüksek ifade için 5 puan verilmiştir.

Ölçeğin güvenirliği için iç tutarlık katsayısı Cronbach Alfa, .91 olarak hesaplanmıştır. Bu değer ölçekte bulunan maddelerin güvenirliğinin yüksek olduğunu göstermektedir. 
Madde Puan Aralıkları

\begin{tabular}{ll}
\hline Tamamen Katılıyorum & $4,20-5.00$ \\
Katılıyorum & $3,40-4,19$ \\
Kararsızım & $2,60-3,39$ \\
Katılmıyorum & $1,80-2,59$ \\
Hiç Katılmıyorum & $1,00-1,79$ \\
\hline
\end{tabular}

\subsection{Verilerin Toplanması ve Analizi}

Araştırmada veriler okulöncesi ve sınıf öğretmenlerinin "Değer Öğretiminde Kullanılan Etkinlikler ve Değer Öğretimine illişkin Görüşler Ölçeği"'ne vermiş oldukları cevaplardan elde edilmiştir. Araştırmada elde edilen verilerin analizinde SPSS 22 paket programı kullanılmıştır. Ölçekteki sorular 5 ayrı grup olarak değerlendirilmiştir. Verilerin normal dağılıp dağılmadığına bakmak için Kolmogorov-Smirnov ve Shapiro-Wilk testleri yapılmıştır. Bu testler sonucunda $p$ değeri 0,05 'ten büyük olduğundan verilerin normal dağılıma sahip olduğu görülmüştür. Elde edilen verilerin analizinde; frekans, yüzde, aritmetik ortalama, t-testi ve tek yönlü varyans analizi (one way anova) kullanılmıştır.

\section{BULGULAR}

Tablo 1

Öğretmenlerin Değer Öğretimine Illişkin Görüşlerinin Cinsiyete Göre Bağımsız t-Testi Sonuçları

\begin{tabular}{lllllll}
\hline Cinsiyet & $\mathbf{N}$ & $\overline{\mathrm{X}}$ & $\mathbf{s s}$ & $\mathbf{d f}$ & $\mathbf{t}$ & $\mathbf{p}$ \\
\hline Erkek & 44 & 126,79 & 17,24 & 78 & 1,893 & 0,062 \\
Kadın & 36 & 133,83 & 15,63 & & & \\
\hline $\mathrm{p}>0,05$ & & & & & &
\end{tabular}

Tablo 1 incelendiğinde öğretmenlerin değerler öğretimine ilişkin görüşleri ile cinsiyet değişkeni arasında anlamlı bir farklılığın olmadığı görülmektedir $\left[\mathrm{t}_{(78)}=1,893 ; p>0,05\right]$.

Tablo 2

Öğretmenlerin Değer Öğretimine Yönelik Görüşlerinin Mesleki Kıdeme Göre Tek Yölü Varyans Analizi (Oneway Anova) Sonuçları

\begin{tabular}{cccccc}
\hline Gruplar & $\mathbf{N}$ & $\overline{\mathrm{X}}$ & $\mathbf{S}$ & $\mathbf{F}$ & $\mathbf{p}$ \\
\hline $1-9$ YII & 40 & 129,82 & 17,01 & & \\
$10-19$ Yıl & 25 & 130,52 & 16,99 & 0,261 & 0,977 \\
20 Yıl ve Üzeri & 15 & 129,96 & 17,09 & & \\
\hline
\end{tabular}

$\mathrm{p}>0,05$

Tablo 2 incelendiğinde $p$ değerinin 0,977 olduğu görülmektedir. Söz konusu değer 0,05'den büyük olduğu için, Öğretmenlerin değer öğretimine yönelik görüşlerinin mesleki kıdemlerine göre istatistiksel olarak anlamlı bir farklılık göstermediği görülmektedir. 
Tablo 3

Öğretmenlerin Değer Öğretimine Iliş̧kin Görüşlerinin Branşlara Göre t Testi Sonuçları

\begin{tabular}{llllll}
\hline Cinsiyet & $\mathbf{N}$ & $\overline{\mathrm{X}}$ & $\mathbf{d f}$ & $\mathbf{t}$ & $\mathbf{p}$ \\
\hline $\begin{array}{l}\text { Sınıf } \\
\text { Öğretmenliği }\end{array}$ & 51 & 140,95 & 78 & 3,76 & 0,00 \\
$\begin{array}{l}\text { Okul Öncesi } \\
\text { Öğretmenliği }\end{array}$ & 29 & 126,05 & & & \\
\hline P<0,05 & & & & \\
\hline
\end{tabular}

$$
\mathrm{P}<0,05
$$

Tablo 3 incelendiğinde öğretmenlerin Değer Öğretimine ilişkin görüşleri ile branşları arasında istatistiksel olarak anlamlı bir farklılık olduğu görülmektedir $\left[t_{(78)}=3,76 ; p<0,05\right]$. Bu farkın okul öncesi öğretmenliği ile sınıf öğretmenliği arasında, sınıf öğretmenliği lehine olduğu tespit edilmiştir.

Tablo 4

Öğretmenlerin Değer Öğretimine Yönelik Görüşlerinin Aritmetik Ortalama ve Standart Sapması

\begin{tabular}{lccccc}
\hline & $\mathrm{N}$ & Min. Puan & Max. Puan & $\overline{\mathrm{X}}$ & $\mathrm{S}$ \\
\cline { 2 - 6 } $\begin{array}{l}\text { Ölçeğin } \\
\text { Tümü }\end{array}$ & 80 & 1,00 & 5,00 & 3,82 & 1,571 \\
& & & & & \\
\end{tabular}

Tablo 4'e göre öğretmenlerin değerler öğretimine yönelik genel algıları 1,00 ile 5,00 arasında değişmektedir. Öğretmenlerin algı puanlarının aritmetik ortalamasının 3,95 olduğu görülmektedir. Öğretmenlerin değerler eğitimine yönelik aldıkları genel algı puanı $\left(\bar{X}_{=3,82}\right)$ algı seçeneklerinden "katılıyorum" seçeneği arasında yer almaktadır. Buna göre, öğretmenlerin değerler öğretimine yönelik algılarının iyi düzeye (katılıyorum=3,40-4,19 puan aralığı) olduğu söylenebilir.

\section{TARTIŞMA VE SONUÇ}

Araştırma sonucunda, öğretmenlerin değer öğretimine yönelik görüşlerinin cinsiyete ve mesleki kıdeme göre anlamlı bir farklııı göstermediği belirlenmiştir. Sınıf öğretmenleri ile okul öncesi öğretmenlerinin değer öğretimine ilişkin görüşleri arasında ise anlamlı bir farklılık olduğu, bu farklıı̆ın sınıf öğretmenleri lehine olduğu tespit edilmiştir. Okul öncesi ve sınıf öğretmenlerinin değer öğretimine yönelik genel algı puanlarının ise olumlu olduğu $(\bar{X}=3,82)$ görülmüştür.

Araştırma sonuçları önceki araştırma sonuçlarıyla karşılaştırıldığında benzerlik ve farklılıklara rastlanmaktadır. Araştırmada sonucunda öğretmenlerin değer eğitimine bakış açılarının olumlu olduğu görülmektedir. Elde edilen bu sonuç Yazıcı (2013) ve Fidan (2009) tarıfından yapılan araştırmasından elde ettiği sonuçla benzerlik göstermektedir.

Araştırmada öğretmenlerin değer eğitimine ilişkin görüşlerinde cinsiyet değişkeni açısından anlamlı bir farklılık bulunmamıştır. Benzer sonuçlara Arslan'ın (2007) yaptığı çalışmada da rastlanmaktadır. Bununla birlikte Altunay ve Yalçınkaya (2011), Dilmaç ve arkadaşları (2008) tarafından yapılan araştırmada bayan öğretmen adaylarının erkek öğretmen adaylarına göre değerlere daha fazla önem verdikleri sonucuna ulaşılmıştır. Bu sonuç araştırmadan elde edilen sonuçla farklılık göstermektedir. Diğer yandan Başçiftçi, Güleç, Akdoğan ve Koç (2011) tarafından yapılan araştırmada öğretmen adaylarının değer tercihleri 
cinsiyetlerine göre; güç, başarı, uyarılma, özdenetim, geleneksellik, güvenlik alt boyutlarında anlamlı bir farklılık göstermezken hazcılık, evrensellik, yardımseverlik, uyum, yetenek, çaba alt boyutlarında anlamlı bir farklılık gösterdiği tespit edilmiştir.

Araştırmadan elde edilen bir diğer sonuç öğretmenlerin değer eğitimine ilişkin görüşleri ile mesleki kıdem değişkeni arasında anlamlı bir farklılık bulunmamasıdır. Elde edilen bu sonuç Yaşaroğlu'nun (2014) araştırmasında elde ettiği sonuçla farklılık göstermektedir. Yaşaroğlu (2014) sınıf öğretmenleri üzerinde yapmış olduğu araştırmasında; öğretmenlerin değer eğitimine yönelik tutumları ile mesleki kıdem değişkeni arasında anlamlı bir farklılık olduğunu ortaya koymuştur.

\section{KAYNAKLAR}

Alpöge, G. (2011). Okul öncesinde değer eğitimi. Ankara: Bilgi Yayınevi.

Altunay, E. ve Yalçınkaya, M. (2011). Öğretmen adaylarının bilgi toplumunda değerlere ilişkin görüşlerinin bazı değişkenler açısından incelenmesi. Educational Administration: Theory and Practice, 17(1), 5-28.

Akbaş, O. (2004). Türk milli eğitim sisteminin duyuşsal amaçlarının ilköğretim II. Kademedeki gerçekleşme derecesinin değerlendirilmesi. Yayınlanmamış Doktora Tezi. Gazi Üniversitesi, Eğitim Bilimleri Enstitüsü.

Arslan, R. (2007). Öğretmen görüşlerine göre ilköğretim birinci basamaktaki öğrencilerin temel bilgi, beceri ve değerleri kazanma düzeyleri. Yayınlanmamış Yüksek Lisans Tezi. Anadolu Üniversitesi, Sosyal Bilimler Enstitüsü.

Aydın, M. Z. ve Akyol, Gürler, Ş. (2013). Okulda değerler eğitimi. Ankara: Nobel Yayınları.

Aydın, E. ve Sulak, S. E. (2012). Sınıf öğretmeni adaylarının "değer" kavramına yönelik metafor algıları. Bartın Üniversitesi Eğitim Fakültesi Dergisi, 4(2), 482-500.

Bal, U. G. (2004). Çocuklar ve değerler eğitimi. Çoluk Çocuk Dergisi, 45, 18-20.

Balcı, F. A. ve Yanpar Yelken, T. (2010). Ilköğretim öğretmenlerinin "değer" kavramına yükledikleri anlamlar. Hacettepe Üniversitesi Eğitim Fakültesi Dergisi, 39(39), 81-90.

Bacanlı, H. ve Dombaycı, M. A. (2012). Dğer eğitiminde değer boyutlandırma yaklaşımı. II. Uluslararası Değerler Eğitimi Sempozyumu, İstanbul.

Başçiftçi, F., Güleç, N., Akdoğan, T. ve Koç, Z. (2011). Öğretmen adaylarının değer tercihleri ile epistemolojik inançlarının incelenmesi. Paper presented at the 2nd International Conference on New Trends in Education and Their Implications, Antalya.

Çetingöz, D. (2015). Okul öncesi eğitimi öğretmen adaylarının değerler eğitiminde öğretmenin rolüne ilişkin görüşleri. TSA. 19, 33-52

Demircioğlu, i. H. ve Tokdemir, M. A. (2008). Değerlerin oluşturulma sürecinde tarih eğitimi: amaç, işlev ve içerik. Değerler Eğitimi Dergisi, 6(15), 69-88.

Deveci, H. (2015). Value education through distance learning: opinions of students who already completed value education. Turkish Online Journal of Distance EducationTOJDE 16(1), 112-126.

Dilmaç, B. (2002). Insanca değerler eğitimi, Ankara: Nobel Yayınları.

Dilmaç, B., Bozgeyikli, H. ve Çıkılı, Y. (2008). Öğretmen adaylarının değer algılarının farklı değişkenler açısından incelenmesi. Değerler Eğitimi Dergisi, 6, 16, 69-91. 
Doğanay, A. (2006). Değerler eğitimi. C. Öztürk (Ed.). Hayat bilgisi ve sosyal bilgiler öğretimi "yapılandırmacı bir yaklaşım". Ankara: Pegem Akademi Yayıncılık.

Dönmez, C. ve Yazıcı, K. (2008). T.C. Inkılâp tarihi ve Atatürkçülük konularının öğretimi. Ankara: Nobel Yayın Dağıtım.

Elbir, B. ve Bağcı, C. (2013). "Değerler eğitimi üzerine yapılmış lisansüstü düzeyindeki çalışmaların değerlendirilmesi", Turkish Studies, 8(1), 1321-1333.

Fidan, N. K. (2009). Öğretmen adaylarının değer öğretimine ilişkin görüşleri. Kuramsal Eğitim Bilim Dergisi, 2(2), 1-18.

Genç, S. ve Eryaman, Y. (2007). Değişen değerler ve yeni eğitim paradigması, www.aku.edu.tr/AKU/DosyaYonetimi (Erişim Tarihi:13.10.2016).

İşcan, C. D. (2014). Öğretmen adaylarının değerler eğitimindeki tercihleri. Elementary Education Online, 13(4), 1203-1222.

Kale, N. (2007). Nasıl bir değerler eğitimi? Değerler ve Eğitimi Uluslararası Sempozyumu (26-28 Kasım 2004), 313- 322, İstanbul: Değerler Eğitimi Merkezi Yayınları.

Karasar, N. (2009). Bilimsel araştırma yöntemleri. Ankara: Nobel Yayınları.

MEB. (2005). Illköğretim sosyal bilgiler dersi 4.-5. sınıf öğretim programı ve kılavuzu. Ankara: MEB Yayınları.

Ogelman, H. G. ve Sarıkaya, H. E. (2015). Okul öncesi eğitimi öğretmenlerinin değerler eğitimi konusundaki görüşleri: Denizli ili örneği. Sakarya Üniversitesi Eğitim Fakültesi Dergisi, 29, 81-100.

Oğuz, E. (2012). Öğretmen adaylarının değerler ve değerler eğitimine ilişkin görüşleri. Kuram ve Uygulamada Eğitim Bilimleri Dergisi, 12(2), 1309-1325.

Öztürk, E. (2009). Hayat bilgisi dersinde değer eğitimi ve örnek uygulamalar. Selahiddin Ögülmüş, (Ed.), Illköğretim hayat bilgisi öğretimi ve öğretmen el kitabı. Ankara: Pegem Akademi Yayınları.

Şahinkayası, Y. ve Kelleci, Ö. (2013). Elementary school teachers' views on values education. Procedia - Social and Behavioral Sciences, 93, 116-120.

Şen, Ü. (2007). Milli Eğitim Bakanlığı'nın 2005 yılında tavsiye ettiği 100 temel eser yoluyla Türkçe eğitiminde değerler öğretimi üzerine bir araştırma. Yayımlanmamış Yüksek Lisans Tezi. Gazi Üniversitesi, Eğitim Bilimleri Enstitüsü.

Tahiroğlu, M., Yıldırım, T. ve Çetin, T. (2010). Değer eğitimi yöntemlerine uygun geliştirilen çevre eğitimi etkinliğinin, ilköğretim 7. sınıf öğrencilerinin çevreye ilişkin tutumlarına etkisi. Selçuk Üniversitesi Ahmet Keleşoğlu Eğitim Fakültesi Dergisi, 30, 231-248.

Tokdemir, M. A. (2016). Tarih öğretmenlerinin değerler ve değer eğitimi hakkındaki görüşleri. International Periodical for the Languages, Literature and History of Turkish or Turkic. 11(3), 2225-2242.

Thornberg, R. (2008). The lack of professional knowledge in values education. Teaching and Teacher Education, 24, 1791-1798.

Turan, S. ve Aktan, D. (2008). Okul hayatında var olan ve olması düşünülen sosyal değerler. Türk Eğitim Bilimleri Dergisi, 6(2), 227-259. 
Yalar, T. (2010). Ilköğretim sosyal bilgiler programında değerler eğitiminin mevcut durumunun belirlenmesi ve öğretmenlere yönelik bir program modülü geliştirme. Yayımlanmamış Doktora Tezi. Mersin Üniversitesi, Sosyal Bilimler Enstitüsü.

Yaşaroğlu, C. (2014). Sınıf öğretmenlerinin değerler eğitimine yönelik tutumlarının çeşitli değişkenler açısından incelenmesi. International Journal of Social Science. 27, 503-515.

Yazar, T. ve Erkuş, S. (2013). Okul öncesi öğretmenlerinin okul öncesi eğitim programındaki değerler eğitimine ilişkin görüşlerinin değerlendirilmesi. Dicle Üniversitesi Ziya Gökalp Eğitim Fakültesi Dergisi, 20, 196-211.

Yazıcı, K. (2006). Değerler eğitimine genel bir bakış, Türklük Bilimi Araştırmaları Dergisi, 19, 499-522.

Yazıcı, M. (2013). Değerler eğitimine gönüllü katılan öğretmenlerin profili ve görüşleri. The Journal of Academic Social Science Studies International Journal of SocialScience, 6(2), 995-1023.

Yıldırım, K. (2009). Values education experiences of Turkish class teachers: A phenomonological approah. Eurasian Journal of Educational Research, 35, 165-184.

Yeşil, R. ve Aydın, D. (2007). Demokratik değerlerin eğitiminde yöntem ve zamanlama. Türkiye Sosyal Araştırmalar Dergisi, 11(2), 65-84. 


\section{SUMMARY}

The values are judges that adopted by community or individuals, considered to meet the social needs, directing people to the correct behaviors, providing continuity and integrity of society, separate the right and wrong and enabling us to live a peaceful life (Balcı ve Yanpar Yelken, 2010; Fidan, 2009; MEB, 2005; Öztürk, 2009; Turan ve Aktan, 2008). The values are perception, thinking, behavior, rules or securities that all kinds of ideological or divine origin accepted by society or people (Dönmez ve Yazıcı, 2008). In other words, value is tend to a situation favor other (Genç ve Eryaman, 2007). Value of the properties are as follows:

1. The values are combiner cases adopted by communities or individuals.

2. Criterions are believed to meet the social needs of the community.

3. Judges are interests not only awareness but also emotion and excitement.

4. Values are motives located in the consciousness of the individual and directing behavior.

5. Value of the difference from the norm is to have more general and an abstract quality. Because values include norms (MEB,2005).

According to Yazıcı (2006) functions of the system of values as follows:

1. The values assign to goal and direction to individual.

2. The values give direction to the principles of individual and social activities

3 . The values help to judge the behaviors of individuals.

4. The values provide knowing individuals from others and what is expected from him.

5. The values provide discriminating individual's right and wrong, right and unfair, likable and dislikable, the moral and the nonmoral.

A property of value is also then obtained. Therefore the values salvaging is a matter of education. School is one effective tool used to win value individuals. Therefore in research were examinedopinions of the teachers about value education.

In this research, the opinions of primary school teachers and pre-school teachers on value education were evaluated. The population of the study constitutes 260 primary school teachers and pre-school teachers in the Bartın city center. The sample consists 80 primary school teachers and pre-school teachers, which are chosen by randomly sampling method. Survey method was used in the research. In research, it is to answer the following subproblems:

1. Is there a significant difference by gender opinions of the teachers about value education?

2. Is there a significant difference by professional experience opinions of the teachers about value education?

3. Is there a significant difference by their branchs opinions of the teachers about value education?

4. How is the public opinions of the teachers about value education?

It was used data collection tool "Activities used in value education and scale of opinions on value education" developed by Akbaş (2004). Items options consist of "I never disagree", "I do not agree", "I undecided", "I agree" and "I totally agree".

Items limitations:

I totally agree: $4.20-5.00$

I agree: 3.40-4.19

I undecided: 2.60-3.39

I do not agree: 1.80-2.59

I never disagree: 1.00-1.79. 
It was calculated as .91 internal consistency coefficient Cronbach's alpha for reliability instrument. In the analysis of datas used frequency, percentage, mean, independent groups ttest and one way anova. As a result of research was found nonsignificant difference according to gender and professional experience views on the value education of teachers. It was found significant primary school teachers' favor, between primary school teachers and pre-school teachers. It was determined general perception score $(x=3.82)$ opinions of primary school teachers and pre-school teachers on value education. In this case it may said_positive general perceptions primary school teachers and pre-school teachers on value education. It was found some similarities and differences in the survey results compared with the results of previous research. Result of the research was found positive general perceptions primary school teachers and pre-school teachers on value education. These results are similar to with the result obtained in the study by Yazıcı (2013). In research was found nonsignificant difference according to gender views on the value education of teachers. Similar results are also seen in study by Arslan (2007). However, it was found give more importance to the values of female pre-service teachers than male pre-service teachers in the research by Altunay and Yalçınkaya (2011). This result differ shows from result obtained from the research. Another result obtained from research is find nonsignificant difference between professional experience variable and perceptions primary school teachers and pre-school teachers on value education. This result differ shows from result obtained from the research by Yaşaroğlu (2014). Yaşaroğlu (2014) was found significant a difference between professional experience variable and perceptions primary school teachers on value education in his study on primary school teachers. 